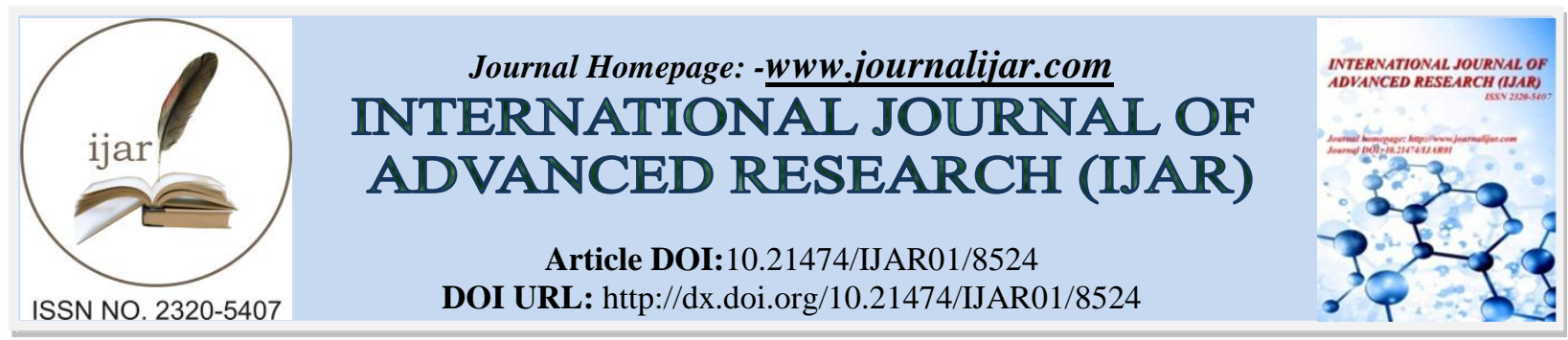

RESEARCH ARTICLE

\title{
PORTFOLIO - INNOVATIVE TOOL FOR SELF-ASSESSMENT AND IMPROVEMENT OF QUALITY OF EDUCATION IN BULGARIA.
}

\author{
Rumyana T. Gyoreva. \\ Assistant prof., Ph.D, South-West University "Neofit Rilski", Blagoevgrad, Faculty of Pedagogy2700 Blagoevgrad, \\ 66 Ivan Mihailov Street, Bulgaria.
}

\section{Manuscript Info}

Manuscript History

Received: 06 December 2018

Final Accepted: 08 January 2019

Published: February 2019

Key words:-

portfolios, self-assessment, monitoring, quality of education.

\section{Abstract}

The portfolio is a widespread tool for formative assessment. There are many publications in support of this claim. Less literature describes the capabilities of the portfolio as a tool for self-assessment, in particular for self-evaluation of the school as an institution.

This is a reason to consider the chances of the portfolio as a technology for self-assessment that provides useful information and liaise between performance measurement and quality, and facilitates motivation of teachers and leaders to achieve the objectives and results, and school development. The article analyzes the legislation in the Republic of Bulgaria, which regulates the development and implementation of portfolio in education and the educational process. In theoretical aspect explore the benefits that portfolio provided as an integrative model for self-assessment in the Bulgarian school in two contexts: students and teachers who carry out individual self-assessment and self-evaluation of the school as an institution.

There are recommendations for monitoring, analysis and evaluation of the standards achieved in school institutions using portfolio in order to improve the quality of education.

Copy Right, IJAR, 2019,. All rights reserved.

\section{Introduction:-}

In recent years, the Bulgarian education are implemented several reforms towards decentralization and granting autonomy to schools and kindergartens. The focus is on providing added value and high quality of education in all areas of school institutions. The changes require a new style of teaching and learning, collaborative relationships, adaptive environment of tolerance and positivism, a new style of management and others. The peculiarities of management related to communication and discussion of management decisions with the teachers and other stakeholders (flat management); researching and analyzing the needs and satisfaction of pedagogical staff, parents, students, public; development and implementation of systems for quality management education and other characteristics of democratic governance.

The problem of quality education in recent years has been the subject of many discussions, publications and various opinions and recommendations both in Bulgaria and in Europe and worldwide. This is understandable because of the education of the nation depends on the future prospects of economic development of each country. So the 'knowledge economy' is leading to policies for better education.

Corresponding Author:- R umyana T. Gyoreva, Ph.D.

Address:- South-West University "Neofit Rilski", Blagoevgrad, Faculty of Pedagogy 2700

Blagoevgrad, 66 Ivan Mihailov Street, Bulgaria. 
Law on preschool and school education, operating in Bulgaria from 2015 regulates the requirement for quality management in educational institutions through inspection and self-evaluation. The inspection is carried out by independent administration Council of Ministers of the Republic of Bulgaria - National Education Inspectorate and the self-assessment is a personal concern of schools and kindergartens. At present this requirement is not yet realized, but yet to be implemented.

In the process of decentralization and autonomy securing, maintaining and developing the quality of educational services is primarily the responsibility of the manager of the school organization and his team. The external evaluation only verifies the self-assessment of schools, provide support and recommendations for further development of the institution.

The Law on preschool and school education are defined state educational standards that all institutions are obliged to respect. Their performance is evaluated in institutions. State educational standards, a set of mandatory requirements for the results in the system of preschool and school education, and the conditions and processes for achieving them relate to:

1. Preschool education.

2. Utilization of the Bulgarian literary language.

3. Curriculum.

4. The general education.

5. The specialized training.

6. Acquisition of professional qualifications.

7. Inclusive Education.

8. Civil, health, environmental and intercultural education.

9. Assessment of learning outcomes of students.

10. The information and documents.

11. The institutions.

12. Physical environment and information and library provision of kindergartens, schools and centers of support for personal development.

13. Textbooks and teaching aids.

14. Status and professional development of teachers, directors and other pedagogical specialists.

15. Quality management in institutions.

16. Inspection of kindergartens and schools.

17. Financing of the institutions.

18. Labor standardization and remuneration.

19. Organization of activities in school education (Art. 22 of the Preschool and School Education Act).

Apart from these mandatory requirements, each institution (school, kindergarten, center to support personal development) formulate its mission, vision, goals and priorities.

The following questions arise: How can measure the achievement of the standards?, How can you summarize performance information?, What are the mechanisms for determining the efficiency of the organization according to standards and its own priorities and goals?, What are the possibilities of the portfolio as a tool for self-assessment?, How efficiently can use the portfolio? And others.

Relation quality education - monitoring and assessing the quality of education is viewed in the context of the portfolio as modern technology and specific tool for self-assessment. In school organizations can be considered different types of portfolios: the teacher; the pupil; the Director; the achievements of students from different stages of education or separate class; certain educational nuclei or parts thereof; a group of school subjects with the same subject area or individual subjects; portfolio of the organization or its individual activities. Can be added, and other segments of the educational process. Whatever incisions to be made, it is undisputed that the use of portfolio is an opportunity for training, assessment and lifelong learning. We will comment on two model portfolios: the student and the teacher as individual portfolios, and portfolios of the school. Important for evaluation and self-assessment is a portfolio director. In terms of autonomy, however, the management of school institutions is carried out with all stakeholders, so that the subject will not be affected.

The concept of portfolio linguistic seen as derived from Italian (portafoglio), cognate with French portefeuille ("folder, wallet"), from the Latin verb portāre ("to carry") and folium ("sheet") - (Wiktionary- 
https://en.wiktionary.org/wiki/portfolio). In the context of educational services and their evaluation concept is seen as a record of activities, achievements, best practices, reflection. The structure of the portfolio depends on the goals, but its main advantage is that summarize information, and it can serve for analysis, evaluation, self-assessment, as well as evidence of achieved standards and success.

The objectives of teacher portfolio can be: promoting of the activity, share the best practices and problems, career development, evaluation (self-evaluation) and others. A number of authors define the characteristics and peculiarities of teacher portfolio (Gospodinov. 2011; Gyurova and Bozhilova. 2008; Gospodinov. 2011; Popova. 2008; Stefanova. 2013; Novikova. 2004; Novikova et al. 2009; Seldin et al. 2010; Macpherson. 2014; Barrett. 2001, Attinello et al. 2006, etc.). Summarized their formulations for the specificity of the portfolio of the teacher are reduced to:

1. Synthesis and publicity work of the teacher.

2. Targeted selection of materials and documents presenting pedagogical and creative work of the teacher.

3. Planning work.

4. A reliable tool for measuring and assessing the quality of teaching and learning in the work of teachers and the quality achieved in the training and education of students.

5. Presentation of the learning process, supported by facts and evidence about the effectiveness of teaching (comments, tasks and tests used for assessment records or presentations of the learning process, etc.).

6. Feedback - from students and parents.

7. Materials visited courses for maintenance or ongoing training implemented in the educational process and led to the improvement of teaching, new teaching methods or assessment etc.

8. Means of introspection and pedagogical supervision.

9. Critical presentation of their own development and setting goals for self-development as learners.

10. Evaluation (self-evaluation) and analysis of skills used in teaching practice, with a focus on improving the education of students, supported by evidence.

11. Communication with colleagues, students and parents - provoking formal and informal discussions presented practices sharing "working" methods and forms of education and training, problem solving cases and situations application forms mentoring.

The portfolio of the teacher is required under the Law on preschool and school education (Art. 226 of the Act). The State Education Standard for professional development of pedagogical specialists defines in detail the objectives, content and functions of the teacher portfolio. The standard regulates the requirements for the structure of the portfolio, namely the materials presented in it to prove the involvement of teachers in the implementation of the policy of the institution, striving for teacher improvement results achieved by students, the dynamics of the performances of the teacher and students (Art. 66 of Ordinance No. 12 of 01.09.2016). This structure supports the self-assessment in school organizations and objective implementation of the attestation process, which as well as self-assessment to be implemented in schools and kindergartens in Bulgaria (Art. 66 of Ordinance No. 12 of 01.09.2016). The standard defines the basic features that teacher portfolio must fulfill: a representative function (to characterize the philosophy of teaching and teacher qualification supported by evidence); developing (directed to the improvement of the teacher); evaluation (to evaluate the performance of teachers and support its formation skills for objective self-assessment); communicative, providing feedback to stakeholders (Art. 68 of Ordinance No. 12 of 01.09.2016). With these characteristics of teacher portfolio, it can be defined as a tool for developing and assessing which goals are met and with what efficiency, and what still needs to be done.

Like the teacher portfolio is a portfolio of the student. It is defined as the intentional, systematic and organized collection of educational materials and information about its achievements and development, creativity, interests, In one or more areas that serve for evaluation and self-assessment of students in a given period. The aim is to help students to acquire skills for self-reflection, self-awareness, improvement include overall objectives of the class or setting their own ones and track their achievement, creating skills for planning and organizing their own activities. Student portfolio provides structured information not only to the students but also teachers and parents. The aim of the legislation is to turn it into a comprehensive project that allows the receiving of children into the education system and leaving her to track achievements and progress their possibilities for application of acquired knowledge and skills in new problem situations and the skills for learning and their appearances, interests, abilities, needs. The portfolio of the student creates opportunities to add to its responsibility as a party in the learning process, motivate and engage students in training purposes. As a kind of design work, which includes planning, execution and analysis of achievements, teaches children entrepreneurship, critical thinking and creativity. 
Depending on the age of the students, the portfolio is more or less independent work. It can be created and maintained by the teacher (for the youngest pupils), collaboration between teacher and student (for older students) and private development of students (when acquire the necessary competencies for self-structuring). For better information and communication in developing and maintaining a portfolio can participate and parents.

Student portfolio usually contains a variety of materials from the activities of students in school or extracurricular activities (tests, exercises for learning and skills, creativity, projects, material from the life of class, etc.) An important aspect of the content of the portfolio is the presence of goals, analytical part containing the extent of their achievement and forecast future development goals and achievements of the child.

Institutional portfolio is less described and tested in comparison with teacher's portfolio and student's portfolio. Its potential can be realized in a team effort, understanding and commitment of the staff of the educational institution. As write Gordon Joyes, Lisa Gray and Elizabeth Hartnell-Young, if these conditions are not met and the connection between the assessment of the activities of the institution and its development effort will fail (Joyes et al. 2010).

Understanding school portfolio in kindergartens and schools in the country associated with the school site, but practice shows that he has more promotional than developing and evaluation functions. School portfolio should serve to support self-assessment and self-regulation, to improve the planning and implementation of activities based on improved knowledge of the learning process and management. The main advantage of the portfolio of the institution that maintains a database of empirical evidence of activities that prove achieved and unmet goals, and serve as performance analysis and future planning. The statutory requirement for the presence of institutional portfolio lies in state educational standard for inspecting schools and kindergartens. It stipulates that one of the types of information to analyze the inspection team of the National Education Inspectorate is portfolio educational institution (Art. 2 of Ordinance No 15 of 8 December 2016). The possibilities for structuring the individual sections of the portfolio are varied: to represent the main priorities and activities of the institution; design and educational technology training; best practices for training and management; providing feedback to stakeholders; educational products offered by the organization and other items. To ensure comprehensive coverage and achieve transformative effect, it is necessary between these elements take place relationship. The key is to increase the motivation, responsibility and commitment of staff to the mission, vision, goals of the organization and provide evidence of the achievement of the objectives of the institution and the quality of educational services.

The main functions of the portfolio can be reduced to three:

1. Information - inform achieved standards, goals, priorities and assess the degree of implementation.

2. Motivating - motivate staff to plan new goals and objectives.

3. Developed - an opportunity to track progress

Portfolio as a set of information for students, teachers and the institution can be considered as an intermediate body between the mission, vision, priorities of the organization, strategies to achieve them, mandatory standards, targets and tasks on the one hand and monitoring and subsequent analysis and discussions on the other. Through monitoring, which is a way to explore the reality at some point in time and method of management by providing information, analyze the evidence of the institution's activities, as information collected in the portfolio (Figure 1).

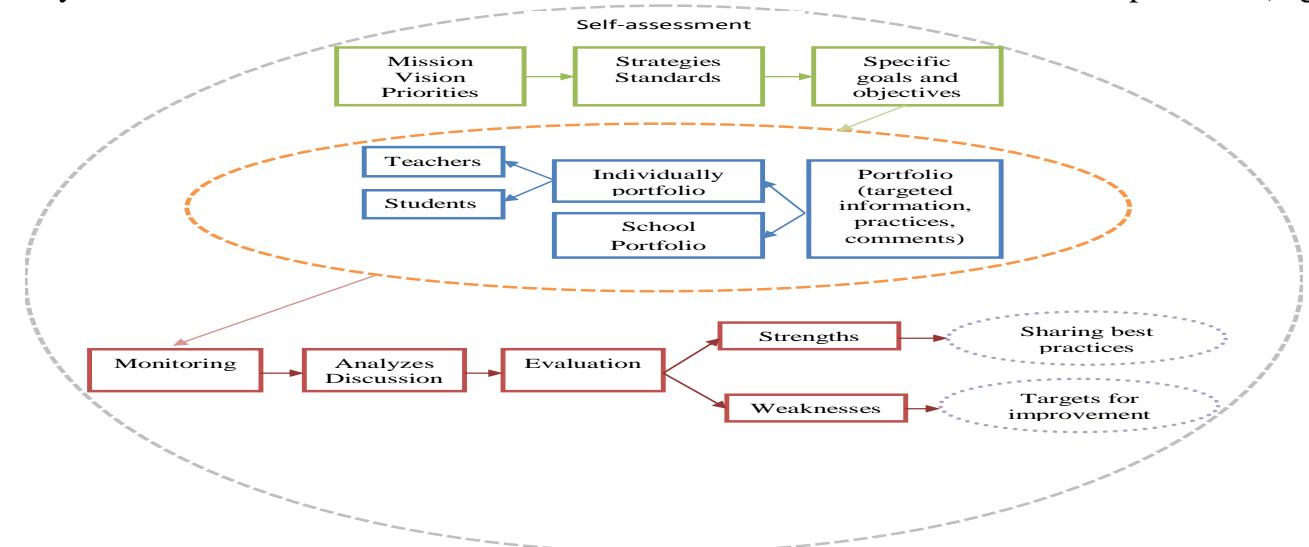

Figure 1:-Relationship between planning and analysis of results achieved using the capabilities of the portfolio 
The portfolio is not constant, and dynamically changing depending on the development of processes, entities and bodies. To achieve its objectives, it should not be seen as unnecessary records. The portfolio should not contain much information, but only one that shows trends and contributions in training and management. Portfolios can be effective and provoke debate and interest only when together people with common goals and interests who wish to share their experiences and explore foreign, who are concerned about the achievement of the organization's priorities, its own development and improvement. Moreover, as the writing Tartwijk et al., in order to achieve effective implementation, it is necessary objectives of the portfolio in advance to be discussed with stakeholders and they are aware of and engaged with them (Tartwijk et al. 2007: 69-79). Another condition for the effectiveness of the portfolio was previously clarified the audience to which it is directed, precise selection of components type and content, as well as accompanying evidence. It should provoke and stimulate a dialogue and reflection, analysis and conclusions, otherwise will be only collection of materials.

The characteristics of the portfolio shows that one of the main objectives of the portfolio is to support the development of an objective system of evaluation and self-assessment. It provides an opportunity for reflexive analysis of the development, achievements and unfulfilled goals and objectives. Besides, teaching professionals, involved in self-evaluation become more engaged, more responsible, more motivated for better outcomes. The benefits of the portfolio as a tool for self-assessment are mainly limited to the following:

\section{For students:}

1. Possibility students to assess their own performance.

2. Comparison own achievements of students with those of other students.

3. Opportunity for self-assessment of the learning process of students.

4. Summarizing information on the formation skills.

5. Comparison between the set learning objectives and their implementation.

6. Awareness of the extent of implementation of the standards they should achieve student.

7. Awareness and self-evaluation of achieved competencies and personal qualities.

8. Self development of independent learning skills.

9. Study the preferences of students to extracurricular activities.

10. Analysis of the impact of student participation in extracurricular activities to improve their motivation for learning.

11. Study the benefits of participation of students in project-based learning to achieve their educational goals.

12. Formulation of training needs and choice of future educational tasks And other.

\section{For teachers}

1. Self-assessment of the effectiveness of training programs.

2. Self-assessment of standards achieved by pupils as a result of the work of the teacher.

3. Awareness for the development of theoretical and practical knowledge, skills and attitudes of students as a result of teaching.

4. Comparative analysis and assessment of student performance in school compared their results from national and international research.

5. Self-assessment of the effectiveness of the use of teacher training methods and forms of assessment and analysis of the favorite for students and "working" forms of assessment and analysis.

6. Self-assessment of the development of personal and professional qualities of the teacher.

7. Awareness to participate in training activities, scientific forums and other forms of improving skills of the teacher and acquired training credits.

8. Analysis of the benefits of acquired competences during the training to improve the effectiveness of the learning process.

9. Self-reflection on their own performance and development of teachers, as well as the achievements of individual students, school classes, students from a stage of training And other.

\section{For institution}

1. Use as an archive of evidence for self-assessment of progress.

2. Self-assessment of achievements and unmet strategic objectives and policies of the institution or individual aspects of its activities.

3. Comparative analysis and self-assessment activities of the institution at some point in time compared to previous achievements and results. 
4. Measurement achieved quality of education as compared to the expected results, objectives, standards and criteria.

5. Self-assessment of implementation and effectiveness of the curriculum according to set their objectives and expected results.

6. Making an analysis on various criteria.

7. Review and self-assessment of acquired competences of the teaching staff through participation in training courses and qualifications.

8. Study of the commitment of teachers and students to the organization's goals.

9. Study the contribution of teachers and students for improving the image of the institution.

10. Monitoring and analysis of the effect of visited teachers qualification forms.

11. Monitoring and analysis of the effect of visited for teachers qualification forms.

12. Self-assessment of the quality of the established educational environment at school.

13. Ability to analyze and improvements in management, training, education, learning environment, teacher qualifications (depending on their needs), partnerships with stakeholders And other.

14. Self-assessment of the effects of introduced innovations.

15. Support the effectiveness of teaching by monitoring the learning objectives.

16. Ability to motivate teachers and students.

17. Awareness necessary topics for training and qualification of teachers.

18. Study of the qualities of the team such as discipline, perseverance, tenacity and responsibility in performing tasks and improvement of these qualities to the development of school culture.

19. Self-assessment of the effectiveness of the interaction between school and family, etc.

Creating links between portfolios allow the creation of a comprehensive self-assessment system, a set of individual indicators that allow the various stakeholders to use this data and get acquainted with: the institution; the achievement of goals and objectives of the students; methods and tools that use teachers; what quality of education students receive, etc. (Stefanakis 2002: 137). It is a difficult task, but its systematic implementation focuses evidence of successful acts and practices in educational institutions.

Under terms of presentation options portfolio are paper or electronic, individually (for use only by the holder) or public (for example electronic site). E-portfolio provides greater opportunities for the purpose of self-assessment. Eportfolio allows dialogue aimed at a large number of target groups, offered a statement of views that provide feedback on the achieved quality of educational services in the institution. Simultaneously, e-portfolio allows networking contact. Thus, except for self-assessment, it can be used for mutual evaluation of organizations registered in the contact group. Groups can share ideas, best practices, opinions. Joint monitoring has the characteristics of mentoring and benefits for all parties involved in the process. The condition for this process to be effective is the presence of mutual respect and trust, recognition of the professional status of both sides - the holder of the portfolio and observers. Another condition for the effectiveness of the mutual evaluation process and exchange of practices is this process not a single act, but to continuously and purposefully.

It can be summarized that the portfolio is a valuable tool for self-assessment of school organizations. Its use is associated mostly with the development of institutions. This is because based on information collected in the portfolio, school teams mutually affect results, exchange ideas, analyze successful methods and practices. Teachers as well as students, motivate each other for better performance. In school institution establishes a new team culture, by promoting cooperation and commitment to the prosperity of the organization.

Self-assessment in school organizations through portfolios as a tool for self-assessment is a reliable way to make an unbiased assessment and continuous monitoring of the progress of the institution. The active participation of the teachers creates real prerequisites for applying the principles of a learning organization, to improve the skills of communication and dialogue, and for the actual participation of teachers and other stakeholders in the management of the school. The objective self-assessment, analysis of results and design suggestions and ideas for the development of the institution, largely ensure that the standards and quality assurance. 


\section{References:-}

1. Attinello, J. R., Lare, D., \& Waters, F. (2006). The value of teacher portfolios for evaluation and professional growth. NASSP Bulletin, 90(2).

2. Barrett, H.C. (2001). „Electronic Portfolios“, Educational Technology: An Encyclopedia, eds. ABC-CLIO, http://www.electronicportfolios.com/portfolios/encyclopediaentry.htm.

3. Gospodinov, D. (2011). YElektronnoto uchitelsko portfolio. V: Teoretichen seminar na katedra „Istoriya na pedagogikata i upravleniye na obrazovaniyeto“ po sluchay 25 - godishninata na Fakulteta po pedagogika pri SU „Sv. Kliment Okhridski“. Sbornik dokladi, S. Deal - YEmiliya Nedyalkova.

4. Gyurova, V., Bozhilova, V. (2008). Portfolioto na prepodavatelya, S., YEvropres.

5. Joyes, G., Gray, L., \& Hartnell-Young, E. (2010). Effective practice with e-portfolios: How can the UK experience inform implementation? Australasian Journal of Educational Technology. 26 (1) 15-27 https://ajet.org.au/index.php/AJET/article/view/1099/354.

6. Macpherson, A. (2014). Developing your Teaching Portfolio. The Centre for Academic Growth. British Columbia. KPU.

7. Novikova T. (2004). Papka individual'nykh uchebnykh dostizheniy ,portfolio“: federal'nyye rekomendatsii i mestnyy opyt. Direktor shkoly. № 7, s. 13-15; №8, s. 13-21.;

8. Novikova T.G., Pinskaya M. A., Prutchenkov A. S. (2009). Portfolio pedagoga kak sredstvo otsenki i fiksatsii professional'nykh dostizheniy. Zhurnal „Munitsipal'noye obrazovaniye: innovatsii i eksperiment“, kn. 4.

9. Ordinance No. 12 of 01.09.2016 on the status and professional development of teachers, directors and other pedagogical specialists (prom. SG, iss. 75 of 27.09.2016, in force since 27.09.2016), MES - SG, iss. 75 of 27 September 2016.

10. Ordinance No. 15 of 08.12 .2016 on the inspection of nurseries and schools (prom. SG., iss. 100 of 16.12.2016).

11. Preschool and School Education Act, prom. SG, iss. 79 of 13 October 2015, (in force since 01.08.2016), amended and supplemented (SG, iss. $99 \quad$ of $12 \quad$ December 2017) https://www.lex.bg/bg/laws/ldoc/2136641509.

12. Seldin P., J. E. Miller \& Cl. A. Seldin (2010). The Teaching Portfolio: A Practical Guide to Improved Performance and Promotion/Tenure Decisions. 4th Edition. San Francisco. Jossey-Bass.

13. Stefanakis, E. (2002) Multiple Intelligences and Portfolios. Portsmouth: Heinemann.

14. Stefanova, M. (2013). Uchenicheskoto portfolio (instrument za priobshchavane na uchenitsite kam tsennostta na uchilishchnoto obrazovaniye; instrument za otsenka na kachestvoto na obucheniyeto; instrument za samootsenka ot uchenitsite na tekhniya napredak; yelement ot savkupnata otsenka na uchitelya za uchebno-

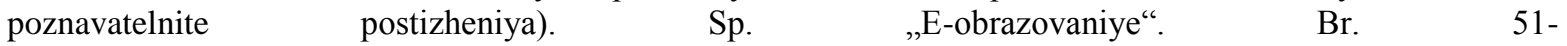
https://www.academia.edu/4142976/Student_Portfolio_in_Bulgarian_.

15. Van Tartwijk, J., Driessen, E., van der Vleuten, C., \& Stokking, K. (2007). Factors influencing the successful introduction of portfolios. Quality in Higher Education, 13(1), 69-79. 